\title{
Effects of Cinnamon on Diabetes
}

Yusra Hussain ${ }^{1}$, Munawar Ali ${ }^{2}$, Faizan Ghani ${ }^{3}$, Muhammad Imran ${ }^{*}, 4$, Aamira Hashmi ${ }^{5}$, Wajahat Hussain ${ }^{6}$, Muhammad Hashim Raza ${ }^{4}$

${ }^{1}$ Mayo Hospital Lahore, 54000, Pakistan

${ }^{2}$ Bahawal Victoria Hospital, Bahawalpur, 63100, Pakistan

${ }^{3}$ District Headquarter Hospital, Toba Take Singh, 36050, Pakistan

${ }^{4}$ District Headquarter Hospital, Layyah, 31050, Pakistan

${ }^{5}$ District Headquarter Hospital, Muzaffargarh, 34200, Pakistan

${ }^{6}$ Tehsil Headquarter Hospital, Kallar Syedan, District Rawalpindi, 47520, Pakistan

A R T I C L E IN F O

Article history:

Received: 09 April, 2018

Accepted: 20 May, 2018

Online: 22 May, 2018

Keywords:

Diabetes

Effects of Cinnamon

\begin{abstract}
A B S T R A C T
Diabetes is a condition of the body in which blood sugar level is higher than the normal average value. It is considered as a major cause of morbidity worldwide. According to the data reported in 2015,420 million people had diabetes worldwide, type 2 diabetes account for $85 \%$ of these cases. This shows $9.2 \%$ of the overall world population of adults is suffering from diabetes with their number increasing with every year. It occurs in both men and women equally, increasing the early death risk of the individual. A detailed review and analysis of research published in various publications and online research sites including; Pub Med, Web of Science, Biological, SciVerse Science Direct, CINAHL and The Cochrane Library. 4 Researches were selected on C. zeylanicum (two in-vitro, two in-vivo). But no human study was available. In-vitro $C$. zeylanicum showed potential to inhibit the enzyme pancreatic a-Jamylase and a-glucosidase which in turn can reduce post prandial glucose absorption through the intestine, can also increase glucose uptake at cellular level membrane translocation of GLT-4. Increase metabolism of glucose and synthesis of glycogen and insulin release is stimulated as well. With potentially cause activity at insulin receptors. The favorable effects of $C$. zeylanicum in animals are diabetes related weight reduction, blood fasting glucose level was also reduced. LDL and HbAlc also show improvements. Cinnamomum zeylanicum shows various useful effects both in vitro and in vivo as a therapeutic agent for diabetes. Further study and research is needed to evaluate any unwanted effects.
\end{abstract}

\section{Introduction}

All over the world, diabetes is the major cause of morbidity and mortality, around 350 million of the world population comprising of adults are suffering from it. According to a data published in the year 2012, it is expected that it will increase to double the value by the year 2030, while most of it is expected in countries with middle-level income such as Asia and Africa [1]. The total health care cost for the patients of diabetes reaches to $12 \%$ of the total expenditure in health care. The economic effect of this cost is important for the low and middle-income societies. Diabetes is a

*Corresponding Author Muhammad Imran, DHQ Hospital, Layyah,

Email: imranmerani247@gmail.com

www.astesj.com

https://dx.doi.org/10.25046/aj030308 disease which is a risk factor for a lot of life-threatening conditions such as cardiovascular and organ failure. $85 \%$ of the patients suffering from diabetes have type 2 diabetes having main features of insulin resistance, hyperinsulinaemia, b-cell dysfunction leading to b-cell failure. Currently pharmacological intervention is made to correct or modify the above conditions. Currently, in the USA $82 \%$ patients suffering from diabetes are on oral glycemic control or insulin while $18 \%$ are not taking any medications [2]. Studies on various aspects of medication and patient adherence has suggested that patients are usually not very adherent to using medicine leading to poor glycemic control and long-term complications. Some of the reasons for such behaviour is 
hypoglycemia and complex drug regime. Lack of proper understanding of the disease and social believes [3].

Studies have also shown that $84 \%$ of the population living in non-developed countries believe in alternative and herbal medicine. Lack of better regime and methods to improve compliance has led to patients in both developed and underdeveloped parts of the world to rely on herbal and alternate methods. It is estimated that in underdeveloped $>85 \%$ and even in USA $>70 \%$ of patients still rely on these alternate treatments.

Latest research on these various sources has proved them to be quite useful in overall glycemic control and metabolism of lipids, and capillary function [4].

The genus Cinnamon consists of 300 species and four of them are used to obtain "cinnamon spice". (Cinnamomum zeylanicum) and (Cinnamomum aromaticum) are most widely used. Many beneficial effects of cinnamon such as anti-inflammation properties control of blood glucose, decreasing heart disease and decreasing cancer [5].

\section{Materials and Methods}

\subsection{Literature search}

Comprehensive analysis and reviewing of literature published on effects of $C$. zeylanicum on diabetes were considered and statement for systematic reviews of interventional studies was done. A detailed search was done on articles published on following databases; Pub Med, Web of Science (v.5.3), Biological Abstracts, SciVerse Scopus, SciVerse Science Direct, CINAHL and The Cochrane Library for studies published before 1 August 2011.

\subsection{Data Collection}

An analysis was done on the body clinical and biochemical parameters; Body weight, Blood fasting glucose, total cholesterol, high-density lipoprotein-cholesterol, triglycerides and insulin. Weight reduction and blood fasting glucose were estimated on the difference of values at the beginning and end of the experiment. On the other parameters the differences of the control and experiment groups were estimated at the end of experiment.

\section{Results}

While performing the search on the criteria following no. of articles were found on the data base. Pub Med $(n=24)$, Web of Science $(\mathrm{n}=16)$, Biological Abstracts $(\mathrm{n}=11)$, SciVerse Scopus $(\mathrm{n}=30)$, Science Direct $(\mathrm{n}=17)$ and CINHAL $(\mathrm{n}=4)$. Four articles were selected in view of the research criteria [6]. Description of studies is shown in table.

\subsection{In-vitro effects}

A study which is done on a molecule, a cell or an organism in a test tube in a laboratory or any other place outside their normal biological environment is called in vitro studies.
Table 1: Description of the studies

\begin{tabular}{|c|c|c|c|c|c|c|}
\hline $\begin{array}{l}\text { S. } \\
\text { N } \\
\text { o }\end{array}$ & $\begin{array}{l}\text { Study } \\
\text { design }\end{array}$ & $\begin{array}{c}\text { Study } \\
\text { description }\end{array}$ & $\begin{array}{c}\text { Paramete } \\
\text { rs } \\
\text { studied }\end{array}$ & $\begin{array}{c}\mathrm{CZ} \\
\text { dose } \\
\mathrm{mg} / \mathrm{kg}\end{array}$ & Subs. used & $\begin{array}{c}\text { Refr } \\
\text { ence } \\
\text { s }\end{array}$ \\
\hline 1 & $\begin{array}{l}\text { In } \\
\text { vitro } \\
\text { Thaila } \\
\text { nd }\end{array}$ & $\begin{array}{l}\text { a-amylase } \\
\text { and rat } \\
\text { intestine } \\
\text { acetone } \\
\text { Powder } \\
\text { (intestinal a- } \\
\text { glucosidase) }\end{array}$ & $\begin{array}{c}\text { Inhibitory } \\
\text { act. On } \\
\text { intestinal } \\
\text { a- } \\
\text { glucosida } \\
\text { se\& } \\
\text { pancreatic } \\
\text { a-amylase }\end{array}$ & $\begin{array}{l}\text { Not } \\
\text { Applic } \\
\text { able }\end{array}$ & $\begin{array}{c}4 \text { type of } \\
\text { cinnamon }(c . \\
\text { zeylanium) } \\
\& \text { acarbose. }\end{array}$ & [7] \\
\hline 2 & $\begin{array}{l}\text { In } \\
\text { vitro } \\
\text { Chile }\end{array}$ & $\begin{array}{c}\text { Porcine } \\
\text { pancreatic } \\
\quad \text { a- } \\
\text { amylase,bak } \\
\text { er's yeast a- } \\
\text { glucosidase }\end{array}$ & $\begin{array}{c}\text { phenolic } \\
\text { content } \\
\text { total, } \\
\text { inhibitory } \\
\text { effect on } \\
\text { a- } \\
\text { amylase, } \\
\text { a- } \\
\text { glucosida } \\
\text { se \&ACE }\end{array}$ & $\begin{array}{l}\text { Not } \\
\text { Applic } \\
\text { able }\end{array}$ & $\begin{array}{l}\text { C.zeylanicu } \\
m \text { \&26 plant } \\
\text { extract }\end{array}$ & [8] \\
\hline 3 & $\begin{array}{c}\text { In } \\
\text { vivo } \\
\text { Saudi } \\
\text { Arabia }\end{array}$ & $\begin{array}{l}\text { Wistar rats: } \\
\text { strep } \\
\text { inducediabe } \\
\text { tes } \\
(\mathrm{n}=45) \text { healt } \\
\text { hy(11) } \\
\text { duration } \\
21 \text { days }\end{array}$ & $\begin{array}{c}\text { weigh of } \\
\text { body, } \\
\text { blood } \\
\text { fasting } \\
\text { glucose } \\
\text { HDL,TG, } \\
\text { total } \\
\text { protein } \\
\text { urea } \\
\text { blood, } \\
\text { creatinine } \\
\text {, uric } \\
\text { acid, } \\
\text { ALT,AST }\end{array}$ & $\begin{array}{l}\text { Not } \\
\text { Applic } \\
\text { able }\end{array}$ & $\begin{array}{l}\text { Nigella sa- } \\
\text { tiva L \& } \\
\text { C.zeylani- } \\
\text { cum oils }\end{array}$ & [9] \\
\hline 4 & $\begin{array}{l}\text { In } \\
\text { vivo } \\
\& \text { in } \\
\text { vitro } \\
\text { India }\end{array}$ & $\begin{array}{l}\text { wistar rat: } \\
\text { strep induce } \\
\text { diabetes(n= } \\
\text { 20)healthy( } \\
\text { 6) duration } \\
2 \text { months }\end{array}$ & $\begin{array}{c}\text { in vivo: } \\
\text { weight of } \\
\text { body, } \\
\text { intake of } \\
\text { fluid, } \\
\text { blood } \\
\text { fasting } \\
\text { glucose, } \\
\text { HB1ac } \\
\text { insulin, L } \\
\text { D50. } \\
\text { In vitro: } \\
\text { pancreatic } \\
\text { insulin } \\
\text { release, } \\
\text { Glycogen } \\
\text { content, } \\
\text { pyruvate } \\
\text { kinase \& } \\
\text { phosphoe } \\
\text { nol, } \\
\text { pyruvate } \\
\text { carboxyki } \\
\text { nase, } \\
\text { activity\& } \\
\text { mRNA } \\
\text { level, } \\
\text { muscle } \\
\text { GT4 } \\
\text { level. }\end{array}$ & 20 & $\begin{array}{c}\text { cinnamalde } \\
\text { hyde } \\
\text { c.zeylanicm } \\
\& \\
\text { glibenclami } \\
\text { de. }\end{array}$ & [10] \\
\hline
\end{tabular}




\subsection{Regulation of enzymes of carbohydrate metabolism, glycolysis and gluconeogenesis}

A study monitored the inhibitory action of cinnamon species (four types) on a-Glucosidase (intestine) and a-Amylase of the pancreas, while also studying the effect they produce in combination to acarbose. It was concluded that all the four types of cinnamon studies has an inhibitory effect on maltase, sucrose, and pancreatic a-amylase. A cinnamon named as Thai cinnamon extract had the most powerful and potent inhibitory effect on intestinal maltase [11]. C. zeylanicium had the most potent and strong inhibitory effect on intestinal sucrose and pancreatic aamylase. With IC50 (max inhibitory concentration half) with values $0.44 \_0.02$ and $1.21 \_0.02 \mathrm{mg} / \mathrm{ml}$, respectively. But this has a less effect on inhibition of pancreatic a-amylase, int. maltase, and int. Sucrose than acarbose. However when the cinnanmon extract was used in combination to acarbose the results were enhanced on all the three enzymes $[11,12]$. A study shown C. zeylanicum extracts to have an a-glucosidase inhibition effects and it is dose dependent. (100\% at $2.6 \mathrm{mg}$ and $95 \%$ at $0.6 \mathrm{mg}$ of dry sample) and a very strong inhibition effect on a-amylase $(78 \%, 76 \%$ and $52 \%$ at $25 \mathrm{mg}, 12.4 \mathrm{mg}$ and $6 \mathrm{mg}$ of dry sample, respectively) [8].

\subsection{In-vivo effects}

Study which is done on a living body either it is an organism or a cell is called in vivo, usually on animals which may also include human and plants are selected for such trails.

\subsection{Decrease in level of $L D L, H b A l c$ and insulin resistance}

It is reported in a study, when a strep induce diabetic rat was evaluated it had a greater increase in LDL -cholesterol level in comparison to the control by about $64.6 \%$. But when such rat was treated with the cinnamon extract it showed a significant $(\mathrm{p}<0.01)$ reduction in the level of LDL-cholesterol in comparison to the nontreated strep induce diabetic rate [9]. A trail was conducted to see the effect of cinnamon on the HbAlc level when treated with the cinnamon extracts, through the trail it was seen that the level of HBA1c is not changed in the healthy rats. (from 24_0.22 to $\left.28 \_0.35 \mathrm{mmol} / \mathrm{mol}\right)$ however a very significant increase $(\mathrm{P}<$ 0.001 ) was noted in a non-treated rats (from 33_0.48 to 114_0.47 $\mathrm{mmol} / \mathrm{mol}$ ). The increase of $\mathrm{HbAlc}$ in treated subjects showed a significant value [10].

\subsection{Safety}

It was also evaluated the safety factor of the extracts on the rats by evaluating the effect of $6(100 \mathrm{mg} / \mathrm{kg}), 12(200 \mathrm{mg} / \mathrm{kg})$ and 24 $(400 \mathrm{mg} / \mathrm{kg})$ times the effective dose $(20 \mathrm{mg} / \mathrm{kg})$ of cinnamon on healthy non diabetic rat. On the complete observation the rats showed no changes in their behavior. No death or ataxia was noted with similar excitement and nervousness than non-treated rats. Hepatic parameters i.e. ALT, AST, Bilirubin, Alk. phosphatase and Creatinine were in normal range throughout the study period. The insignificant changes were observed. But over-all safety of the cinnamon extracts was observed in the rats [10].

\section{Discussion}

Diabetes is a disease which affects a large population of the world. A large number of people whom suffer with this disease are also not show compliance to their treatments. A very major reason www.astesj.com for non-compliance on the treatment is the cultural believe in nonmedicinal and herbal treatments. Cinnamon a medicinal herb is widely used for the treatment of diabetes. Above research trails performed comprehensive and systemic trails on effects of cinnamon on blood sugar levels and other body parameters showing some of the few effects. Reviewing the above trails shows C. zeylanicum extracts on diabetes rats has many beneficial effects both in vivo and vitro. C. zeylanicum shows some beneficial effects by lowering post prandial glucose absorption in intestine by inhibiting the enzymes involve in carbohydrate metabolism namely pan. A-amylase and a-glucosidase in rats.

Carbohydrate metabolism is a major step for intestinal glucose absorption, and by using regimes targeting the inhibition of this pathway, a lot of glucose lowering effects can be achieved. Which will over all improve the body sugar level and long/short term adverse effects of the disease. By improving over-all blood glucose levels long term complications like diabetic neuropathy and nephropathy can be prevented. In-vivo trails on diabetic rats also showed no significant adverse effect on organs such as liver and kidney providing a high therapeutic window for further interventions.

In addition to the glucose lowering effects of cinnamon, lipid lowering effects of cinnamon are also shown in detail in the above trails. The exact mechanism by which it is achieved in diabetic rats is not known but it is hypothesized to be the cinnamon high fiber content which in turn can reduce lipid intestinal absorption. Cinnamon also has a high anti-oxidant and a very high vitamin concentration which can also produce additive effect in lipid metabolism. Insulin itself can play a role in lipid metabolism so it can be estimated that consuming cinnamon can increase lipid metabolism due to its effect on insulin stimulation, as insulin stimulation is observed after administration of C. zeylanicum.

The attenuation of weight loss is also observed in diabetics with consumption of $C$. zeylanicum is probably due to better glycemic control achieve after therapy. The reduction in weight of the body of diabetic rat is due to catabolism of protein and fats because of insulin deficiency leading to muscular tissue proteolysis which in turn decrease protein content. Oral therapy with C. zeylanicum improves body weight in diabetic rats due to its effect on insulin stimulation. Apart of effects which are described above there are other very beneficial effects of $C$. zeylanicum, which can be very useful in overall improvement of the pathophysiology of diabetes. Phenol an important constituent of C. zeylanicum shows anti-oxidant properties in vitro which can be very useful in preventing the atherogenesis and may also prevent its progression.

C. zeylanicum has very potent anti-inflammatory effect both in vitro and in vivo which can be very beneficial in preventing the advancement of disease. (AGEs) Advanced glycation endproducts are shown to be the major culprit for the pathological process of diabetes associated micro-vascular and macro-vascular complications, while Proanthocyanidins in cinnamon has an effect to prevent the formation of AGE, which in-turn can prevent a lot of major complications of diabetes and improving over-all health of patients and also improving their quality of life.

The effect of some plants having medicinal properties is also widely studied for the treatment of diabetes and has showed to be 


\section{Y. Hussain et al. / Advances in Science, Technology and Engineering Systems Journal Vol. 3, No. 3, 57-60 (2018)}

very useful. A lot of conventional glucose lowering diabetic drugs are derivative of such medicinal plants. Metformin a very useful and effective oral Glucose lowering drug is an example of such efforts. It was developed as a Galega officinalis to treat diabetes. They have a very high concentration of guanidine, the hypoglycaemic component that leads to the development of metformin.

Up till now over 300 traditional treatments for diabetes have been reported but only a very small number is proven scientifically after medical evaluation and research. But a wide variety of such herbal treatments is available in the market for use and regularly used by the patients which need to be evaluated for their efficacy. These treatments are preferred by the patients. The major issue in using these alternate treatments is the lack of data supporting their benefits over side effects. Research and clinical trials are required for such herbal treatments as they can be very useful if properly used after meticulous trails and research. To properly evaluate their pharmacological properties and their toxic effects it is very important that animal model trails are conducted for their toxicity profile. By finding the effective component of these herbal treatments a very potent and effective medicine could be obtained, which will be beneficial for over-all health and reducing complications in diabetic patients.

By performing systemic reviews and analysis a gap between traditional (herbal) and allopathic medicine can be bridged. In combining the present knowledge while highlighting the areas which have potential for further research we can over-come the gap between the treatments of both traditional and allopathic ways. The above analysis has a lot of strengths and limitations. Strength includes that the analysis of some of the major research done in the field on all leading data resources are comprehensively analyzed and reviewed, and major effects are listed. While there are a few limitations as well such as un-ability to verify from the authors of the researches about the specific type of cinnamon used. But considering that all the researchers analyzed are from the countries where cinnamon is cultivated it is expected that they all use "True Cinnamon". Heterogenicity is also present in different studies so to estimate the exact effect on Weight reduction (WR), Blood fasting glucose (BFG), Total cholesterol and LDL is not recorded. Heterogenicity is also present due to difference of sample size and the method which was used to induce diabetes in rats. Plus no study was there to evaluate the effect of Cinnamon on humans, therefore a lot of care and considerations are to be done when these results are to be applied on humans. But strong evidence is there which proves the efficacy of $C$. zeylanicum in diabetes, therefore research need to be done to evaluate its exact pharmacological benefit in humans.

\section{Conclusion}

The above review and analysis show that cinnamon $C$. zeylanicum has definitive beneficial effects both in vitro and in vivo for the treatment of diabetes. It can be efficacious for the better glycemic control, overall lipid profile, can decrease insulin reduction and can prevent long-term potentially dangerous complications associated with the disease. Plus, no significant side effect was shown. However further evaluation is required to show the exact therapeutically and pharmacological effects on human body and to establish its safety.

\section{Conflict of Interest}

The authors declare no conflict of interest.

\section{References}

[1] Cowie, C.C., Rust, K.F., Ford, E.S., Eberhardt, M.S., Byrd-Holt, D.D., Li, C., Williams, D.E., Gregg, E.W., Bainbridge, K.E., Saydah, S.H. and Geiss, L.S., 2009. Full accounting of diabetes and pre-diabetes in the US population in 1988-1994 and 2005-2006. Diabetes care, 32(2), pp.287-294.

[2] Wild, S., Roglic, G., Green, A., Sicree, R. and King, H., 2004. Global prevalence of diabetes: estimates for the year 2000 and projections for 2030 . Diabetes care, 27(5), pp.1047-1053.

[3] Kahn, B.B., 1998. Type 2 diabetes: when insulin secretion fails to compensate for insulin resistance. Cell, 92(5), pp.593-596.

[4] Bhat, M., Zinjarde, S.S., Bhargava, S.Y., Kumar, A.R. and Joshi, B.N., 2011. Antidiabetic Indian plants: a good source of potent amylase inhibitors. Evidence-Based Complementary and Alternative Medicine, 2011.

[5] Sima, A.A., Kamiya, H. and Li, Z.G., 2004. Insulin, C-peptide, hyperglycemia, and central nervous system complications in diabetes. European journal of pharmacology, 490(1-3), pp.187-197.

[6] Saltiel, A.R. and Kahn, C.R., 2001. Insulin signalling and the regulation of glucose and lipid metabolism. Nature, 414(6865), p.799.

[7] Adisakwattana, S., Lerdsuwankij, O., Poputtachai, U., Minipun, A. and Suparpprom, C., 2011. Inhibitory activity of cinnamon bark species and their combination effect with acarbose against intestinal $\alpha$-glucosidase and pancreatic $\alpha$-amylase. Plant Foods for Human Nutrition, 66(2), pp.143-148.

[8] Ranilla, L.G., Kwon, Y.I., Apostolidis, E. and Shetty, K., 2010. Phenolic compounds, antioxidant activity and in vitro inhibitory potential against key enzymes relevant for hyperglycemia and hypertension of commonly used medicinal plants, herbs and spices in Latin America. Bioresource technology, 101(12), pp.4676-4689.

[9] Al-Logmani, A.S. and Zari, T.A., 2009. Effects of Nigella sativa L. and Cinnamomum zeylanicum Blume oils on some physiological parameters in streptozotocin-induced diabetic rats. Boletín latinoamericano y del caribe de plantas medicinales y aromáticas, 8(2).

[10] Anand, P., Murali, K.Y., Tandon, V., Murthy, P.S. and Chandra, R., 2010. Insulinotropic effect of cinnamaldehyde on transcriptional regulation of pyruvate kinase, phosphoenolpyruvate carboxykinase, and GLUT4 translocation in experimental diabetic rats. Chemico-biological interactions, 186(1), pp.72-81.

[11] World Health Organization. WHO Diabetes Fact Sheet. 2011[22/08/2011]; Available at http://www.who.int/mediacentre/factsheetsfs $312 /$ en/index.html Last accessed 22 August 2011

[12] Wild, S., Roglic, G., Green, A., Sicree, R. and King, H., 2004. Global prevalence of diabetes: estimates for the year 2000 and projections for 2030 . Diabetes care, 27(5), pp.1047-1053. 